\title{
RESEARCH
}

Open Access

\section{Predicting the dynamics of a native Araucaria forest using a distance- independent individual tree-growth model}

\author{
Enrique Orellana ${ }^{1 *}$, Afonso Figueiredo Filho ${ }^{1,2}$, Sylvio Péllico Netto ${ }^{2}$ and Jerome Klaas Vanclay ${ }^{3}$
}

\begin{abstract}
Background: In recent decades, native Araucaria forests in Brazil have become fragmented due to the conversion of forest to agricultural lands and commercial tree plantations. Consequently, the forest dynamics in this forest type have been poorly investigated, as most fragments are poorly structured in terms of tree size and diversity.

Methods: We developed a distance-independent individual tree-growth model to simulate the forest dynamics in a native Araucaria forest located predominantly in southern Brazil. The data were derived from 25 contiguous plots ( 1 ha) established in a protected area left undisturbed for the past 70 years. The plots were measured at 3-year intervals from their establishment in 2002. All trees above a 10-cm diameter at breast height were tagged, identified as to species, and measured. Because this forest type comprises hundreds of tree species, we clustered them into six ecological groups: understory, subcanopy, upper canopy shade-tolerant, upper canopy light-demanding, pioneer, and emergent. The diameter increment, survival, and recruitment sub-models were fitted for each species group, and parameters were implemented in a simulation software to project the forest dynamics. The growth model was validated using independent data collected from another research area of the same forest type. To simulate the forest dynamics, we projected the species group and stand basal areas for 50 years under three different stand-density conditions: low, average, and high.

Results: Emergent species tended to grow in basal area, irrespective of the forest density conditions. Conversely, shade-tolerant species tended to decline over the years. Under low-density conditions, the model showed a growth tendency for the stand basal area, while under average-density conditions, forest growth tended to stabilize within 30 years. Under high-density conditions, the model indicated a decline in the stand basal area from the onset of the simulation, suggesting that under these conditions, the forest has already reached its maximum-stock capacity.

Conclusions: The model validation using independent data indicated close agreement between the observed and estimated values, suggesting the model is consistent in projecting species-group and stand growth. The methodology used in this study for developing the growth model should be tested in other species-rich forests.
\end{abstract}

Keywords: Forest succession, Species group, Araucaria angustifolia

\footnotetext{
* Correspondence: enriqueflorestal@gmail.com

${ }^{1}$ Midwest State University-UNICENTRO-PR, PR 153, Km 7, Riozinho, Irati,

Paraná 84500-000, Brazil

Full list of author information is available at the end of the article
} 


\section{Background}

The humid subtropical forests in South America exhibit a structure similar to that of tropical forests, but with fewer species and a lower tree density (Sands 2005). One of these subtropical forests is the Araucaria forest located primarily in southern Brazil between 20 and $30^{\circ}$ south latitude (Behling and Pillar 2007) and comprised of hundreds of tree species. Araucaria angustifolia (Bert.) O. Kuntze is the most important species of this forest type and is regarded as Brazil's most important native conifer.

Extensive commercial logging has left this forest type in fragments surrounded by agricultural crops, pasture, and grasslands (Koch and Corrêa 2002; Sands 2005). Between 1915 and 1960, Brazil exported 18.5 billion cubic meters of wood, most of it from Araucaria forests. Between 1960 and 1970, over 200,000 ha of Araucaria species were deforested. Today, this ecosystem is considered one of the most threatened in Brazil (Carlucci et al. 2011), and Araucaria angustifolia appears on the IUCN (International Union for Conservation of Nature and Natural Resources) red list of threatened species as critically endangered.

Research on the forest dynamics of native araucarian forests is still incipient, mainly because most of the forest fragments are poorly structured. To gain a better understanding of the forest dynamics, growth models have been developed to evaluate the structure and composition of the forest over time. These powerful tools can be used to explore how the forest will change in response to adversity and stand conditions (Newton 2007).

Because of inherent limitations, modelling approaches such as transition matrices and stand-table projections are no longer recommended to predict stand development in species-rich forests, except where the stand data are available only in summarized form (Vanclay 1994, p.55). Nevertheless, these approaches have been widely applied to simulate the forests dynamics in Brazilian Araucaria forests (Sanquetta 1999; Mello et al. 2003; Stepka et al. 2010; Ebling et al. 2012; Dalla Lana et al. 2015).

Compared to matrix models, individual tree-growth models provide more versatility and a greater richness of detail to simulate growth in mixed forests (Zhao et al. 2004). Many individual tree-growth models have been developed to predict forests dynamics, particularly in the last two decades (Botkin 1993; Liu and Ashton 1998; Chave 1999; Huth and Ditzer 2000; Köhler et al. 2001; Tietjen and Huth 2006; Pütz et al. 2011). Some of these individual tree-based growth models have been used to evaluate the dynamics in tropical forests, but few have been constructed to investigate succession in coniferangiosperm mixed forests in subtropical regions.

This study is the first application of these modeling approaches to araucarian forest fragments in Brazil. The aim was to simulate the dynamics of the ecological species groups and the forest as a whole by using a distanceindependent individual tree-growth model constructed for Brazil's native Araucaria forests.

\section{Methods}

\section{Experimental site}

The study area is part of the Irati National Forest (FLONA; $25.4^{\circ} \mathrm{S}, 50.6^{\circ} \mathrm{W}$ ), a conservation unit that has been protected for over 70 years to encourage research in the forests of southern Brazil. Before the creation of the National Forest, the area underwent selective logging, but it has since been preserved.

The climate is " $\mathrm{Cfb}$ " according to the Köppen classification system, with an average annual rainfall of $1442 \mathrm{~mm}$ and no dry season. The average temperatures are $22^{\circ} \mathrm{C}$ in January and $10{ }^{\circ} \mathrm{C}$ in July, with more than five frosts a year.

The study area was composed of 25 ha sampled as a series of contiguous 1-ha plots $(100 \mathrm{~m} \times 100 \mathrm{~m})$, each subdivided into four $2500-\mathrm{m}^{2}(50 \mathrm{~m} \times 50 \mathrm{~m})$ plots. Beginning in 2002, these plots were measured every 3 years. All trees with a diameter at breast height (DBH) greater than $10 \mathrm{~cm}$ were tagged, measured, and identified to the species level (Figueiredo Filho et al. 2010).

\section{Grouping species}

For highly diverse forests, it is often impractical to fit mathematical models to each species. To reduce the number of parameters, the species should therefore be grouped according to common characteristics (Vanclay 1991a; Purves and Pacala 2008). The species grouping is a key process in developing growth models for natural forests (Alder and Silva 2000), and several authors have discussed the best way to group them for modeling natural forest dynamics (Vanclay 1991a; Köhler and Huth 1998; Phillips et al. 2002; Gourlet-Fleury et al. 2005; Picard et al. 2010, 2012).

We followed the methodology suggested by Alder et al. (2002) which has also been found useful by Lujan-Soto et al. (2015) in Mexican natural forests. This particular method defines ecological groups according to the position of the tree species on a two-axes graph with the average diameter increment $\left(\mathrm{cm} \cdot \mathrm{yr}^{-1}\right)$ plotted against the 95th percentile of the diameter distribution (Fig. 1) when the diameters at breast height are sorted in ascending order (Alder et al. 2002). The maximum tree size was represented by the 95 th percentile of the size distribution rather than the maximum observed size (King et al. 2006) to prevent bias from any errors or outliers.

Alder's approach clustered species into six ecological groups: understory, subcanopy, upper canopy shade tolerant, upper canopy light demanding, pioneer and emergent. For example, understory species present low diameter growth rates ( $Y$-axis of the graph) and do not reach big 


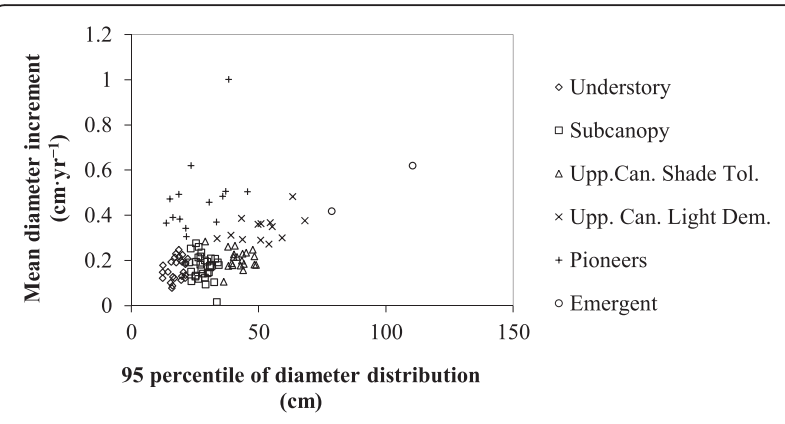

Fig. 1 Araucaria forest data displayed using the two-dimensional species-classification system proposed by Alder et al. (2002). Upp. Can. Shade Tol. = upper canopy shade-tolerant; Upp. Can. Light Dem. = upper canopy light-demanding; incr, increment

sizes (observed on the 95th percentile of diameter distribution, $X$-axis), pioneers present high diameter growth rates and do not reach big sizes. Conversely, emergents present high diameter growth rates and attain big sizes.

While Alder et al. (2002) used cluster analysis to define the species groups, we defined them by plotting the data for the 107 species present in the sample area (25 ha) with more than 10 observations as described above (Fig. 1) and visually compared it to the two-axis graph proposed by Alder et al. (2002).

For the species with few observations $(n<10)$, Alder's approach did not correspond to any known ecological groups in araucarian forests. Therefore, rare species $(n<10)$ were included in the group that most resembled the ecological description of the species as reported in the literature. The complete list of tree species and their ecological groups are presented in the Appendix.

\section{Sub-models to predict forest dynamics}

Sub-models of the diameter increment, survival, and recruitment were fitted for each of the six ecological groups formed. When analyzing forest growth, it is convenient to distinguish one- and two-sided competition. One-sided competition refers to resources such as light, which may be intercepted by overtopping trees and denied to overtopped. In contrast, two-sided competition refers to competition for other resources such as nutrients (Vanclay 1994, p. 161-162; Weiskittel et al. 2011). One-sided competition is well represented by the variable BAL (basal area in larger trees), which indicates the "sociological ranking" of the trees within the plot (Ledermann and Eckmüllner 2004).

The diameter increment sub-model employed an equation (Eq. 1) suggested by Vanclay (1994), p.166,

$$
\begin{aligned}
\ln \left(\Delta d_{i}+0,2\right)= & \beta_{0}+\beta_{1} \cdot \mathrm{DBH}_{i}+\beta_{2} \cdot \ln \mathrm{DBH}_{i} \\
& +\beta_{3} \cdot \mathrm{BAL}_{i}+\beta_{4} \cdot G
\end{aligned}
$$

where $\ln$ is the natural logarithm, $\Delta d_{i}$ is the diameter increment $\left(\mathrm{cm} \cdot \mathrm{yr}^{-1}\right)$ of tree $i, \mathrm{DBH}$ is the diameter at breast height $(\mathrm{cm})$ of tree $i$ calculated for the middle of the interval (Vanclay 1994, p. 158), BAL is the basal area in larger trees $\left(\mathrm{m}^{2} \cdot \mathrm{ha}^{-1}\right)$ of tree $i, G$ is the plot basal area $\left(\mathrm{m}^{2} \cdot \mathrm{ha}^{-1}\right)$, and $\beta_{i}$ are the estimated parameters. This is an easily fit and robust model whose trend line is very similar to those of other models that represent the biological behavior of the diameter increment (Vanclay 2012).

A value of 0.2 was added when fitting the diameter increment to accommodate negative or zero increments (common in tropical forests) and enable the logarithmic transformation of null and negative values, because omitting these observations would have introduced bias and resulted in overestimates of the diameter increment (Vanclay 1991a). Because zero and negative increments are related to several factors that vary among the different data surveys, other studies have used offsets smaller (Vanclay 1991a) or larger than 0.2 (Kariuki et al. 2006; Easdale et al. 2012). A graphical analysis of the data offers an effective way to define the best value to use.

The design of the plots in the sampled area with blocks ( $1 \mathrm{ha})$ divided in quadrats $\left(2500 \mathrm{~m}^{2}\right)$ allowed us to test different plot sizes when fitting diameter increment models. The $p$-value of the variable BAL revealed that quadrats were more effective than blocks when fitting diameter increment, whereas 1-ha blocks were more representative for plot basal area $(G)$. This reflects the reality that competition for water and nutrients may extend over a much larger area than competition for light.

Recruitment was estimated at plot level based on 1-ha plots. All recruitment trees are set to start with $10 \mathrm{~cm}$ of $\mathrm{DBH}$, as this is the minimum-recorded tree size. The number of recruitment trees for each species group are estimated depending on two variables: group basal area $\left(G_{g}\right)$ and stand basal area $(G)$. Group basal area was chosen because more trees of a particular species group will recruit if more density of that group is present within the plot. Stand basal area was included in the model because species groups behave differently according to the density of trees. For example, shade-tolerants tend to benefit in crowded stands compared to lightdemandings.

Recruitments were estimated by (Eq. 2)

$$
\ln (N+1)=\beta_{0}+\beta_{1} \cdot G_{g}+\beta_{2} \cdot G_{g}{ }^{2}+\beta_{3} \cdot G
$$

where $\ln$ is the natural logarithm, $N$ is the number of trees per plot, $G_{g}$ is the basal area of the group $g$ in the plot $\left(\mathrm{m}^{2} \cdot \mathrm{ha}^{-1}\right)$, and $G$ is the plot basal area $\left(\mathrm{m}^{2} \cdot \mathrm{ha}^{-1}\right)$. This approach is consistent with other recruitment models (Vanclay 1992).

Natural variability was included in the model by combining compatible deterministic and stochastic components to estimate tree survival. The deterministic estimate of tree 
survival was performed conventionally (Vanclay 1991b) with logistic regression using the same competition variables (BAL and $G$ ) employed in the diameter increment sub-model as the independent variables. Several transformations of $\mathrm{DBH}$, such as $\mathrm{DBH}^{0.5}, \mathrm{DBH}^{2}$, and $\mathrm{DBH}^{-1}$ were examined to achieve a suitable response curve, with the resulting equation (Eq. 3)

$$
p=\left[1+\exp ^{\left(-\left(\beta_{0}+\beta_{1} \cdot X_{1}+\beta_{2} \cdot X_{2}+\beta_{3} \cdot \operatorname{BAL}_{i}+\beta_{4} \cdot G\right)\right)}\right]^{-1}
$$

where $p$ is the survival probability in three years, $X_{1}$ and $X_{2}$ are transformations of $\mathrm{DBH}, \mathrm{BAL}_{i}$ and $G$ are as defined above.

At each time step of the model, six new records (one for each species group) are added to represent recruitment, with the number of recruit trees in each record estimated by Eq. 2. The survival of each record depends on the number of individuals represented by the record, with mortality simulated deterministically when stem counts are high, and implemented stochastically when stem counts fall below a user-specified threshold (termed 'granularity', and usually set between 0 and 1 per ha). The higher the threshold (granularity), the more run-to-run variation there will be in predictions. If the model-user sets the threshold to 0 the tree survival will be estimated deterministically.

ARC statistical software (Cook and Weisberg 1999) was used to estimate the parameters, which were subsequently included in the simulation software Simile (Muetzelfeldt and Massheder 2003) to model the forest dynamics at the species-group and stand levels by projecting the basal areas. Simile is a useful tool to simulate forest dynamics, because it has several advantages in comparison to other simulation software (Vanclay 2003), particularly the visual interface that makes models accessible to those who are unfamiliar with computer programming (Muetzelfeldt and Massheder 2003).

\section{Evaluation and model validation}

The validation of the growth model was performed with data from another sampled area approximately $100 \mathrm{~km}$ from our study area and located in the protected $\mathrm{Na}$ tional Forest (FLONA) of Três Barras in Santa Catarina state, where 26 1-ha permanent plots were established and measured once in 2004 and again in 2009. The structure of the forest where the data was collected to validate the model is similar to the structure of the sampled area used to parameterize the model, presented in an advanced stage of succession.

The data observed in the field in 2009 were compared to the data projected by the model using the data from the first survey (2004) conducted in the sampled area as input. The comparisons between the projected and observed values were performed in the last survey year (2009), by calculating bias, $(\bar{e})$ precision $\left(s_{e}\right)$ and accuracy $\left(m_{x}\right)$, as suggested by Pretzsch (2009).

$$
\begin{aligned}
& \bar{e}=\frac{\sum_{i=1}^{n}\left(x_{i}-X_{i}\right)}{n} \quad \bar{e}_{\%}=\frac{\bar{e}}{\bar{X}} \times 100 \\
& s_{e}=\sqrt{\frac{\sum_{i=1}^{n}\left(x_{i}-\bar{e}-X_{i}\right)^{2}}{n-1}} \quad s_{e \%}=\frac{s_{e}}{\bar{X}} \times 100 \\
& m_{x}=\sqrt{\left(s_{e}\right)^{2}+(\bar{e})^{2}} \quad m_{x \%}=\frac{m_{x}}{\bar{X}} \times 100
\end{aligned}
$$

where $x_{i}$ is the predicted value of plot $i, X_{i}$ is the observed value of plot $i$ and $n$ is the number of plots.

Bias corresponds to a systematic deviation between observed and estimated values and is calculated by the mean difference between them. The precision indicates the concentration of predicted values around the arithmetic mean of the simulations. It is calculated from the deviation of the simulation from the observed values. The accuracy is calculated from the bias and precision and represents the degree to which the estimation approximates the reality. It can be unsatisfactory or poor when bias and low precision occurs, respectively (Pretzsch 2009).

\section{Simulating forest dynamics}

The model has a 1-ha spatial resolution and a temporal resolution (time-step) of 1 year. We selected three 1-ha plots that have different characteristics in terms of density-the plot with the lowest basal area $\left(15.5 \mathrm{~m}^{2} \cdot \mathrm{ha}^{-1}\right)$ in the sampled area, a plot with an average basal area $\left(29.2 \mathrm{~m}^{2} \cdot \mathrm{ha}^{-1}\right)$, and the plot with the highest basal area $\left(39.1 \mathrm{~m}^{2} \cdot \mathrm{ha}^{-1}\right)$ in the sampled area-to start the model. This allowed us to check its behavior under different conditions in terms of initial density. Basal area projections were made for the species groups $\left(G_{g}\right)$ and stand $(G)$ for a period of 50 years.

\section{Results and discussion}

The diameter increment, survival, and recruitment submodel parameters that were fitted for the species groups are shown in Table 1.

For the diameter-increment models, only the independent variables of the pioneer group (Group 5) were not significant $(p>0.05)$, but they were nevertheless included in the model since the signs of the coefficients exhibited biological consistency. As expected, BAL and $G$ had negative signs, indicating that the increased competition reduced the diameter increment. However, a significant BAL was expected for the pioneer group, as this group has high light demands. One hypothesis to explain the lack of significance of these variables for 
Table 1 Coefficients of the fitted models for diameter increment, survival, and recruitment for each species group

\begin{tabular}{|c|c|c|c|c|c|c|c|}
\hline \multirow[t]{2}{*}{ Sub-model } & \multirow[t]{2}{*}{ Variable } & \multicolumn{6}{|c|}{ Species group } \\
\hline & & $1(n=3428)$ & $2(n=17421)$ & $3(n=7175)$ & $4(n=3777)$ & $5(n=717)$ & $6(n=4504)$ \\
\hline \multirow[t]{5}{*}{$\Delta d$} & $\beta_{0}$ & $-1.3612^{* *}$ & $-1.0942^{* *}$ & $-1.1720^{* *}$ & $-0.9004^{* *}$ & $-2.0994^{*}$ & $-1.6610^{* *}$ \\
\hline & DBH & $-0.0349^{*}$ & $-0.0128^{* *}$ & $-0.0140^{* *}$ & $-0.0058^{* *}$ & -0.0241 & $-0.0162^{* *}$ \\
\hline & In DBH & $0.6303^{* *}$ & $0.3183^{* *}$ & $0.3927^{* *}$ & $0.3132^{* *}$ & 0.7665 & $0.6934^{* *}$ \\
\hline & BAL & $-0.0249^{* *}$ & $-0.0137^{* *}$ & $-0.0230^{* *}$ & $-0.0215^{*}$ & $-0.0208^{\mathrm{a}}$ & $-0.0404^{* *}$ \\
\hline & G & $-0.0239^{* *}$ & $-0.0215^{* *}$ & $-0.0212^{* *}$ & $-0.0239^{* *}$ & -0.0092 & $-0.0242^{* *}$ \\
\hline \multirow[t]{8}{*}{$p$} & $\beta_{0}$ & $8.0148^{* *}$ & $12.9567^{* *}$ & $4.9827^{* *}$ & $1.9897^{*}$ & $-7.4890^{*}$ & $4.0419^{* *}$ \\
\hline & DBH & $-0.1018^{* *}$ & & $-0.0314^{* *}$ & & $-0.2569^{* *}$ & $0.0597^{*}$ \\
\hline & $\mathrm{DBH}^{0.5}$ & & $-1.3177^{* *}$ & & $0.4638^{*}$ & & \\
\hline & $\mathrm{DBH}^{2}$ & & & & $-0.0004^{*}$ & & $-0.0004^{*}$ \\
\hline & $\mathrm{DBH}^{-1}$ & & $-39.9112^{* *}$ & & & & \\
\hline & In DBH & & & & & $5.2228^{* *}$ & \\
\hline & BAL & $-0.2225^{*}$ & $-0.2755^{* *}$ & $-0.2145^{* *}$ & & & \\
\hline & G & -0.0629 & & & & & \\
\hline \multirow[t]{4}{*}{$N_{\text {recruit }}$} & $\beta_{0}$ & $1.0602^{* *}$ & $1.0212^{*}$ & 0.3648 & 0.1235 & 0.2594 & 0.1941 \\
\hline & $G_{g}$ & $1.1478^{* *}$ & $0.3098^{*}$ & $0.1133^{* *}$ & $0.1382^{* *}$ & 1.7941 & $0.0589^{* *}$ \\
\hline & $G_{g}^{2}$ & -0.2132 & -0.0174 & & & -1.1528 & \\
\hline & G & & & -0.0034 & -0.0071 & & -0.0180 \\
\hline
\end{tabular}

1, understory; 2, subcanopy; 3, upper canopy shade-tolerant; 4, upper canopy light-demanding; 5 , pioneer; 6, emergent

$\Delta d$ diameter increment, $p$ probability of survival for 3 years, $N_{\text {recruit }}$ number of recruitments, $n$ number of observations used for the diameter increment fittings,

$\beta_{0}$, estimated parameter, $B A L$ basal area of larger trees, $D B H$ diameter at breast height, $G$ stand basal area, $G_{g}$ basal area for group $g$

${ }^{\text {a }}$ Natural logarithm (In) applied

${ }^{*} p \leq 0.05,{ }^{* *} p \leq 0.01$

the pioneers may be that this group contains few observations due to the forest being at an advanced stage of succession.

As for survival, the BAL variable was only being significant $(p<0.05)$ for the three shade-tolerant groups, suggesting that larger trees such as the representatives of the emergent and upper canopy light-demanding groups cause mortality in the three shade-tolerant groups. The stand basal area variable $(G)$ was only significant for the understory, indicating that this is the group most affected by density. With respect to recruitment, $G$ was insignificant for the tested models, but because the coefficients were consistent with biological expectations and experience elsewhere (Weiskittel et al. 2011), the variable was retained in the model.

\section{Validation of the growth model and simulations of forest dynamics}

The errors in bias, precision, and accuracy were calculated as percentages (Pretzsch 2009) and are shown in Table 2.

Errors greater than $11 \%$ for the bias, precision, and accuracy were observed in three groups: the understory (G1), upper canopy shade-tolerant (G3) and pioneer groups (G5), but those for the stand basal area $(G)$ did not exceed $3 \%$.
Pioneer groups (G5) exhibited in the largest errors among the species groups, because this is the most diverse species group. Conversely, emergents (G6) exhibited the smallest errors in bias, precision and accuracy as this group is mainly represented by one tree species, namely Araucaria angustifolia (see Appendix).

\section{Simulation of forest dynamics}

After validating the model, it was used to predict the basal area of the species groups and stand (Fig. 2) with 50-year simulations using three plots with different densities: the plot with the lowest basal area (Fig. 2a and b), a plot with an average basal area (Fig. 2c and d), and the plot with the highest basal area (Fig. 2e and f).

For the three plots analyzed, the projections indicated that the basal area tends to grow in emergent species, while that of the shade-tolerant species tends to decline

Table 2 Percentage error in the bias, precision, and accuracy for the species-group and stand basal areas

\begin{tabular}{llrrrrrr}
\hline Error Type & G1 & \multicolumn{1}{c}{ G2 } & G3 & G4 & G5 & G6 & G \\
\hline Bias (\%) & 11.2 & -9.1 & -13.9 & 2.1 & 17.4 & -0.9 & -2.2 \\
Precision (\%) & 19.7 & 5.7 & 24.2 & 8.3 & 28.3 & 5.0 & 2.0 \\
Accuracy (\%) & 22.7 & 10.7 & 27.9 & 8.5 & 33.2 & 5.0 & 3.0
\end{tabular}

G1 understory, G2 subcanopy, G3 upper canopy shade-tolerant, G4 upper canopy light-demanding, G5 pioneer, G6 emergent; $G$ stand basal area 

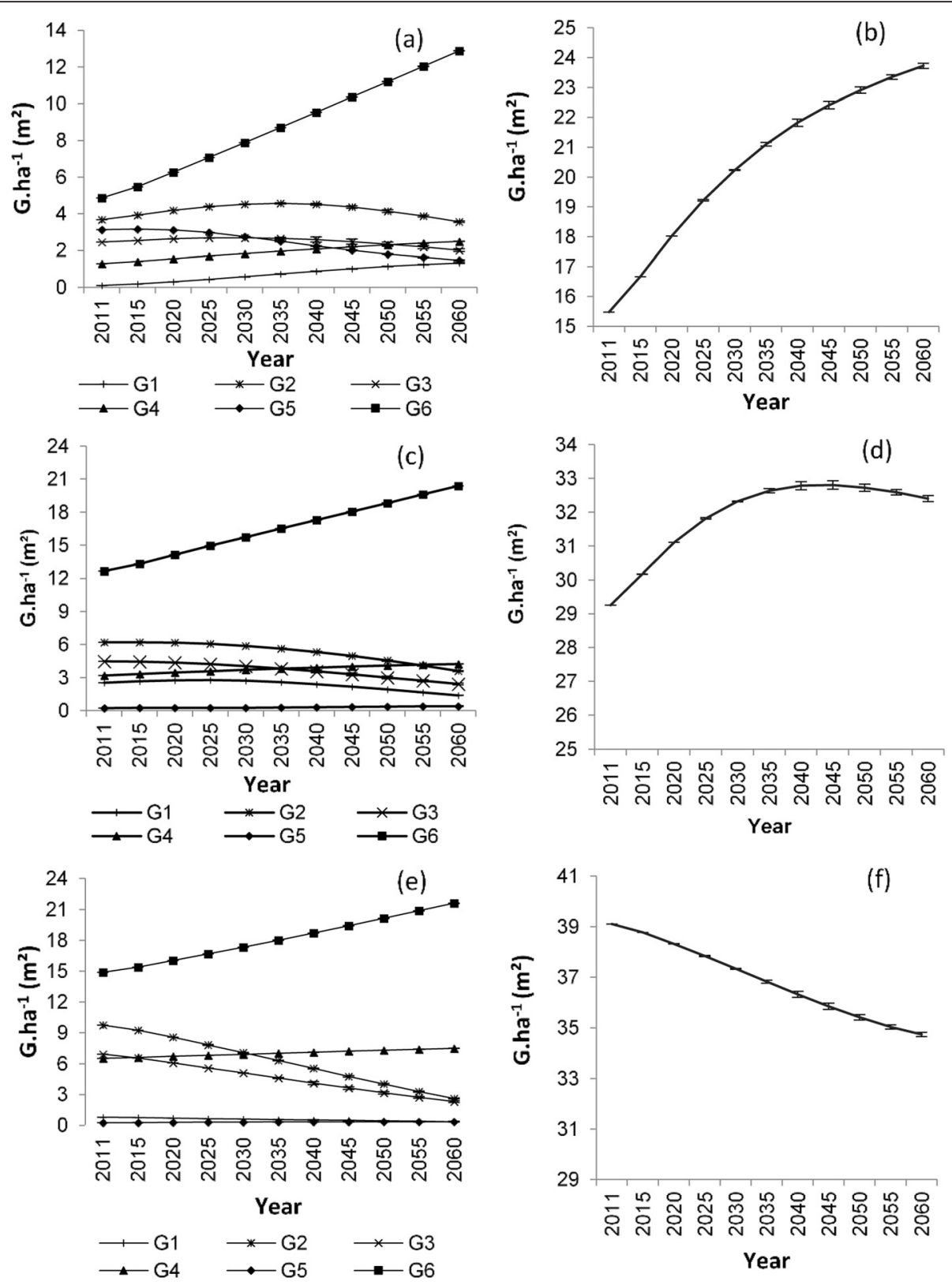

Fig. 2 Fifty-year projections for the species group and stand basal areas. Plot simulations are for low $(\mathbf{a}, \mathbf{b})$, average $(\mathbf{c}$, $\mathbf{d})$, and high densities $(\mathbf{e}, \mathbf{f})$, The curves are averages from 20 simulations (granularity = 0.2), and the vertical bars indicate one standard deviation above and below the mean. G1, understory; G2, subcanopy; G3, upper canopy shade-tolerant; G4, upper canopy light-demanding, G5, pioneer; G6, emergent; G, stand basal area

(understory, subcanopy, and upper canopy shadetolerant) (Fig. 2a, c and e). The model did not show any major change in the basal area of the light-demanding upper canopy over the simulated period.

However, the growth of emergent species is not indefinite, and stabilization occurred close to 200 years after beginning the simulations. This estimate is consistent with the reality observed in the field given that the emergent group is composed solely of Araucaria angustifolia and Ocotea porosa, two of the most long-lived species of this forest type. Ocotea porosa is possibly the most long-lived species and can live for more than 500 years (Carvalho 1994). Studies based on stem analysis (counting annual rings) showed that Araucaria angustifolia can grow for up to $\sim 300$ years (Carvalho 2003).

In the plot with low density, the model showed a growth trend in the stand basal area (Fig. 2b) over the 50-year simulation. The stand basal area growth stabilized in a period similar to that of the emergent species, that is, 200 years after the onset of the simulations. In the plot 
with average density, the model indicated a growth trend for the first 30 years after initiating the simulation (Fig. 2d), after which the growth stabilized.

In the plot with the highest density, the model indicated a decline in stand basal area from the onset of the simulations (Fig. 2f), which was justified by the sharp decline in the basal area of two shade-tolerant groups, the subcanopy and the shade-tolerant upper canopy (Fig. 2e). This decline in the basal area in the high-density plot indicates high mortality rates, suggesting it has already reached its maximum stock.

Other studies have been conducted to evaluate the forest dynamics for different species groups in speciesrich forests by using individual tree-growth models (Köhler and Huth 1998; Huth and Ditzer 2000; Tietjen and Huth 2006; Groeneveld et al. 2009). In most cases, the emergent or climax species showed a growth tendency after 50-year simulations (Köhler and Huth 1998; Huth and Ditzer 2000; Tietjen and Huth 2006), corroborating our results, even though most of these studies applied process-based models.

It is important to consider that comparisons between the results of different models are difficult, because they are constructed for different purposes, parameterized for forests that differ in typology and structure, and reported according to their objectives (Phillips et al. 2004).

Overall, however, the methodology used in this study to project the forest dynamics using an empirical independent-distance individual tree-growth model constructed specifically for Araucaria forests has proven to be an effective means of assessing the forest dynamics in this forest type. We recommend testing the methodology applied in this study with other species-rich forests.

\section{Conclusions}

The validation of the model we constructed using independent data collected from another research area indicated consistency within the model in projecting the stand and ecological species-group growth in the Araucaria forest. The method for grouping the species proposed by Alder et al. (2002) was efficient and, according to the literature, consistent with the ecological characteristics of the main species of the forest.

The 50-year projections for the three plots of the study area revealed that the emergent-species group tends to grow in basal area, irrespective of forest density. Conversely, the model indicated that the shade tolerantspecies groups tend to decline in basal area over time, which was more pronounced in the high-density plot.

Regarding projections for the stand basal area, the model indicated more vigorous growth in the lowdensity plot over the simulated period. Conversely, a decline of basal area was observed over time in the high-density plot, suggesting that this plot has already reached its maximum stock, probably due to mortality in the shade-tolerant species.

In conclusion, we recommend that the growth model we constructed be used to investigate the forest dynamics in Brazilian native Araucaria forests. The methodology used for developing this growth model, particularly the method applied for grouping the species in this study, can also be tested in other species-rich forests.

\section{Appendix}

Table 3 List of tree species classified in order of abundance for each group

\begin{tabular}{|c|c|c|c|c|}
\hline Scientific name & Family & $\overline{\Delta d}$ & $\mathrm{Max}^{\mathrm{a}} \mathrm{DBH}$ & $\mathrm{N} \cdot \mathrm{ha} \mathrm{c}^{-1 \mathrm{a}}$ \\
\hline \multicolumn{5}{|l|}{ Group 1 - Understory } \\
\hline Coussarea contracta (Walp.) Müll.Arg. & Rubiaceae & 0.215 & 30.56 & 16.6 \\
\hline Myrcia hebepetala DC. & Myrtaceae & 0.199 & 31.26 & 8.52 \\
\hline Myrcia splendens (Sw.) DC. & Myrtaceae & 0.133 & 25.78 & 6.12 \\
\hline Allophylus edulis (A.St.-Hil. et al.) Hieron. ex Niederl. & Sapindaceae & 0.146 & 24.67 & 4.56 \\
\hline Curitiba prismatica (D.Legrand) Salywon \& Landrum & Myrtaceae & 0.192 & 31.19 & 3.88 \\
\hline Picrasma crenata (Vell.) Eichler & Simaroubaceae & 0.224 & 29.06 & 2.08 \\
\hline Casearia lasiophylla Eichler & Salicaceae & 0.182 & 23.11 & 1.24 \\
\hline Myrciaria delicatula (DC.) O.Berg & Myrtaceae & 0.207 & 31.67 & 1.20 \\
\hline Allophylus petiolulatus Radlk. & Sapindaceae & 0.189 & 19.10 & 0.96 \\
\hline Xylosma ciliatifolia (Clos) Eichler & Salicaceae & 0.120 & 17.92 & 0.72 \\
\hline Banara tomentosa Clos & Salicaceae & 0.087 & 16.23 & 0.24 \\
\hline Myrciaria tenella (DC.) O.Berg & Myrtaceae & - & 10.82 & 0.24 \\
\hline Sebastiania commersoniana (Baill.) L.B.Sm. \& Downs & Euphorbiaceae & 0.120 & 21.17 & 0.20 \\
\hline Solanum sanctaecatharinae Dunal & Solanaceae & 0.212 & 17.09 & 0.20 \\
\hline Maytenus officinalis Mabb. & Celastraceae & 0.187 & 21.33 & 0.20 \\
\hline
\end{tabular}


Table 3 List of tree species classified in order of abundance for each group (Continued)

\begin{tabular}{|c|c|c|c|c|}
\hline Picramnia parvifolia Engl. & Picramniaceae & 0.246 & 18.62 & 0.20 \\
\hline Eugenia uniflora $\mathrm{L}$. & Myrtaceae & 0.148 & 14.16 & 0.16 \\
\hline Eugenia pluriflora DC. & Myrtaceae & 0.075 & 15.92 & 0.12 \\
\hline Annona sylvatica A.St.-Hil. & Annonaceae & 0.126 & 16.23 & 0.08 \\
\hline Solanum bullatum Vell. & Solanaceae & 0.228 & 17.63 & 0.08 \\
\hline Myrcia lajeana D.Legrand & Myrtaceae & 0.100 & 15.28 & 0.08 \\
\hline Myrcia guianensis (Aubl.) DC. & Myrtaceae & 0.111 & 19.58 & 0.08 \\
\hline Citrus sinensis (L.) Osbeck. & Rutaceae & 0.147 & 12.10 & 0.08 \\
\hline Campomanesia guazumifolia (Cambess.) O.Berg & Myrtaceae & 0.129 & 19.89 & 0.08 \\
\hline Myrceugenia miersiana (Gardner) D.Legrand \& Kausel & Myrtaceae & 0.177 & 11.94 & 0.04 \\
\hline Casearia gossypiosperma Briq. & Salicaceae & 0.191 & 15.66 & 0.04 \\
\hline Strychnos brasiliensis (Spreng.) Mart. & Loganiaceae & 0.120 & 12.10 & 0.04 \\
\hline Actinostemon concolor (Spreng.) Müll.Arg. & Euphorbiaceae & - & 10.50 & 0.04 \\
\hline Baccharis semisserata DC. & Asteraceae & - & 13.20 & 0.04 \\
\hline Blepharocalyx salicifolius (Kunth) O.Berg & Myrtaceae & - & 10.12 & 0.04 \\
\hline Cordyline spectabilis Kunth \& Bouché & Asparagaceae & - & 12.09 & 0.04 \\
\hline Gomidesia affinis (Cambess.) D. Legrand & Myrtaceae & - & 11.36 & 0.04 \\
\hline Trichilia elegans A.Juss. & Meliaceae & & 10.34 & 0.04 \\
\hline \multicolumn{5}{|l|}{ Group 2 - Subcanopy } \\
\hline Ocotea odorifera (Vell.) Rohwer & Lauraceae & 0.141 & 56.34 & 49.84 \\
\hline Ilex paraguariensis A.St.-Hil. & Aquifoliaceae & 0.199 & 43.77 & 47.40 \\
\hline Casearia decandra Jacq. & Salicaceae & 0.181 & 45.96 & 28.24 \\
\hline Syagrus romanzoffiana (Cham.) Glassman & Arecaceae & 0.092 & 36.29 & 16.88 \\
\hline Myrsine umbellata Mart. & Myrsinaceae & 0.132 & 35.97 & 15.36 \\
\hline Casearia sylvestris Sw. & Salicaceae & 0.275 & 34.06 & 11.2 \\
\hline Ilex theezans Mart. ex Reissek & Aquifoliaceae & 0.118 & 40.11 & 9.68 \\
\hline Prunus myrtifolia (L.) Urb. & Rosaceae & 0.176 & 37.91 & 8.92 \\
\hline Dalbergia brasiliensis Vogel & Fabaceae & 0.141 & 38.04 & 8.48 \\
\hline Eugenia involucrata DC. & Myrtaceae & 0.217 & 37.72 & 5.68 \\
\hline Myrciaria floribunda (H.West ex Willd.) O.Berg & Myrtaceae & 0.150 & 35.01 & 5.28 \\
\hline Casearia obliqua Spreng. & Salicaceae & 0.206 & 61.43 & 5.12 \\
\hline Chrysophyllum gonocarpum (Mart. \& Eichler) Engl. & Sapotaceae & 0.234 & 36.92 & 3.52 \\
\hline Jacaranda micrantha Cham. & Bignoniaceae & 0.172 & 39.31 & 3.12 \\
\hline Machaerium stipitatum (DC.) Vogel & Fabaceae & 0.179 & 42.88 & 2.64 \\
\hline Drimys brasiliensis Miers & Winteraceae & 0.191 & 40.43 & 2.12 \\
\hline Cupania vernalis Cambess. & Sapindaceae & 0.169 & 40.27 & 1.80 \\
\hline Inga virescens Benth. & Fabaceae & 0.259 & 33.96 & 1.48 \\
\hline Ilex dumosa Reissek & Aquifoliaceae & 0.127 & 27.76 & 1.12 \\
\hline Chrysophyllum marginatum (Hook. \& Arn.) Radlk. & Sapotaceae & 0.251 & 26.74 & 1.08 \\
\hline Sapium glandulosum (L.) Morong & Euphorbiaceae & 0.106 & 27.53 & 0.96 \\
\hline Lafoensia pacari A.St.-Hil. & Lythraceae & 0.191 & 40.74 & 0.84 \\
\hline Rudgea jasminoides (Cham.) Müll.Arg. & & & & 0.76 \\
\hline Cassia leptophylla Vogel & Fabaceae & 0.146 & 31.04 & 0.72 \\
\hline Zanthoxylum kleinii (R.S.Cowan) P.G.Waterman & Rutaceae & 0.208 & 31.96 & 0.44 \\
\hline Ilex brevicuspis Reissek & Aquifoliaceae & 0.193 & 29.98 & 0.36 \\
\hline
\end{tabular}


Table 3 List of tree species classified in order of abundance for each group (Continued)

\begin{tabular}{|c|c|c|c|c|}
\hline Ficus enormis Mart. ex Miq. & Moraceae & 0.123 & 28.97 & 0.20 \\
\hline Aegiphila integrifolia (Jacq.) B.D.Jackson & Lamiaceae & 0.193 & 25.46 & 0.16 \\
\hline Vitex megapotamica (Spreng.) Moldenke & Lamiaceae & 0.103 & 32.31 & 0.08 \\
\hline Erythroxylum deciduum A.St.-Hil. & Erythroxylaceae & 0.212 & 25.62 & 0.04 \\
\hline Maytenus grandiflora Reissek & Celastraceae & 0.159 & 27.06 & 0.04 \\
\hline Handroanthus albus (Cham.) Mattos & Bignoniaceae & 0.014 & 33.42 & 0.04 \\
\hline Drimys angustifolia Miers & Winteraceae & - & 10.18 & 0.04 \\
\hline Myrsine guianensis (Aubl.) Kuntze & Myrsinaceae & - & 10.12 & 0.04 \\
\hline Ocotea pulchella (Nees \& Mart.) Mez & Lauraceae & - & 14.00 & 0.04 \\
\hline Randia ferox DC. & Rubiaceae & - & 12.25 & 0.04 \\
\hline Symplocos tenuifolia Brand & Symplocaceae & - & 11.87 & 0.04 \\
\hline Symplocos uniflora (Pohl) Benth. & Symplocaceae & - & 19.19 & 0.04 \\
\hline \multicolumn{5}{|l|}{ Group 3 - Upp. canopy shade tolerant } \\
\hline Nectandra grandiflora Nees & Lauraceae & 0.213 & 64.14 & 32.64 \\
\hline Nectandra megapotamica (Spreng.) Mez & Lauraceae & 0.232 & 73.53 & 15.72 \\
\hline Matayba elaeagnoides Radlk. & Sapindaceae & 0.180 & 61.02 & 14.68 \\
\hline Cinnamodendron dinisii Schwacke & Canellaceae & 0.177 & 55.70 & 11.60 \\
\hline Clethra scabra Pers. & Clethraceae & 0.246 & 54.75 & 4.04 \\
\hline Sloanea hirsuta (Schott) Planch. ex Benth. & Elaeocarpaceae & 0.179 & 59.84 & 4.00 \\
\hline Styrax leprosus Hook. \& Arn. & Styracaceae & 0.263 & 47.75 & 3.80 \\
\hline Vernonanthura petiolaris (DC.) H.Rob. & Asteraceae & 0.258 & 46.31 & 1.60 \\
\hline Plinia cauliflora (Mart.) Kausel & Myrtaceae & 0.282 & 33.42 & 1.56 \\
\hline Ocotea corymbosa (Meisn.) Mez & Lauraceae & 0.214 & 48.06 & 1.16 \\
\hline Zanthoxylum rhoifolium Lam. & Rutaceae & 0.185 & 46.63 & 1.00 \\
\hline Lithrea molleoides (Vell.) Engl. & Anacardiaceae & 0.183 & 73.53 & 0.84 \\
\hline Roupala montana Aubl. & Proteaceae & 0.198 & 49.66 & 0.80 \\
\hline Persea major L.E.Kopp & Lauraceae & 0.217 & 49.97 & 0.64 \\
\hline Luehea divaricata Mart. & Malvaceae & 0.174 & 38.67 & 0.48 \\
\hline Cinnamomum amoenum (Nees \& Mart.) Kosterm. & Lauraceae & 0.225 & 40.43 & 0.28 \\
\hline Myrsine coriacea (Sw.) R.Br. ex Roem. \& Schult. & Myrsinaceae & 0.103 & 36.35 & 0.20 \\
\hline Lamanonia ternata Vell. & Cunoniaceae & 0.155 & 43.93 & 0.20 \\
\hline Quillaja brasiliensis (A.St.-Hil. \& Tul.) Mart. & Quillajaceae & 0.175 & 42.97 & 0.20 \\
\hline Eugenia pyriformis Cambess. & Myrtaceae & 0.228 & 43.61 & 0.12 \\
\hline \multicolumn{5}{|l|}{ Group 4 - Upper canopy light demanding } \\
\hline Cedrela fissilis Vell. & Meliaceae & 0.348 & 82.60 & 14.52 \\
\hline Ocotea puberula (Rich.) Nees & Lauraceae & 0.299 & 86.58 & 12.60 \\
\hline Ocotea diospyrifolia (Meisn.) Mez & Lauraceae & 0.271 & 69.07 & 8.88 \\
\hline Campomanesia xanthocarpa (Mart.) O.Berg & Myrtaceae & 0.290 & 49.66 & 5.84 \\
\hline Cinnamomum sellowianum (Nees \& Mart. ex Nees) Kosterm. & Lauraceae & 0.288 & 53.00 & 2.12 \\
\hline Diatenopteryx sorbifolia Radlk. & Sapindaceae & 0.358 & 52.20 & 1.56 \\
\hline Laplacea fruticosa (Schrad.) Kobuski & Theaceae & 0.310 & 49.34 & 1.08 \\
\hline Schefflera morototoni (Aubl.) Maguire et al. & Araliaceae & 0.385 & 46.95 & 0.88 \\
\hline Parapiptadenia rigida (Benth.) Brenan & Fabaceae & 0.481 & 84.13 & 0.80 \\
\hline Ocotea indecora (Schott) Mez & Lauraceae & 0.295 & 34.85 & 0.60 \\
\hline Cabralea canjerana (Vell.) Mart. & Meliaceae & 0.361 & 52.84 & 0.52 \\
\hline
\end{tabular}


Table 3 List of tree species classified in order of abundance for each group (Continued)

\begin{tabular}{|c|c|c|c|c|}
\hline Cryptocarya aschersoniana Mez & Lauraceae & 0.366 & 54.62 & 0.32 \\
\hline Cedrela lilloi C.DC. & Meliaceae & 1.000 & 35.97 & 0.04 \\
\hline \multicolumn{5}{|l|}{ Group 5 - Pioneers } \\
\hline Psychotria vellosiana Benth. & Rubiaceae & 0.483 & 52.52 & 4.40 \\
\hline Vernonanthura discolor (Spreng.) H.Rob. & Asteraceae & 0.369 & 34.38 & 1.36 \\
\hline Piptocarpha angustifolia Dusén & Asteraceae & 0.504 & 42.34 & 1.32 \\
\hline Piptocarpha axillaris (Less.) Baker & Asteraceae & 0.456 & 31.19 & 0.48 \\
\hline Albizia edwallii (Hoehne) Barneby \& J.W.Grimes & Fabaceae & 0.341 & 21.20 & 0.28 \\
\hline Mimosa scabrella Benth. & Fabaceae & 0.504 & 45.55 & 0.20 \\
\hline Anadenanthera colubrina (Vell.) Brenan & Fabaceae & 0.619 & 110.45 & 0.20 \\
\hline Rudgea jasminoides (Cham.) Müll.Arg. & Rubiaceae & 0.305 & 21.65 & 0.16 \\
\hline Cinnamomum glaziovii (Mez) Kosterm. & Lauraceae & 0.491 & 23.24 & 0.04 \\
\hline Sorocea bonplandii (Baill.) W.C.Burger et al. & Moraceae & 0.364 & 12.73 & 0.04 \\
\hline Ormosia arborea (Vell.) Harms & Fabaceae & 0.389 & 16.36 & 0.04 \\
\hline Solanum pseudoquina A.St.-Hil. & Solanaceae & 0.470 & 14.26 & 0.04 \\
\hline Symplocos tetrandra Mart. ex Miq. & Symplocaceae & 0.382 & 18.62 & 0.04 \\
\hline Lonchocarpus muehlbergianus Hassl. & Fabaceae & 0.619 & 22.60 & 0.04 \\
\hline \multicolumn{5}{|l|}{ Group 6 - Emergents } \\
\hline Araucaria angustifolia (Bertol.) Kuntze & Araucariaceae & 0.417 & 121.44 & 41.32 \\
\hline Ocotea porosa (Nees \& Mart.) Barroso & Lauraceae & 0.376 & 155.97 & 18.76 \\
\hline
\end{tabular}

$\overline{\overline{\Delta d}}=$ mean diameter increment $\left(\mathrm{cm} \cdot \mathrm{yr}^{-1}\right)$, Max. $\mathrm{DBH}=$ largest stem $(\mathrm{DBH})$ recorded for each tree species

${ }^{a}$ Data collected in 2011, hyphen (-) on diameter increment column indicates that the tree species recruited in 2011, and therefore growth data is not available

\section{Competing interests}

The authors declare that they have no competing interests.

\section{Authors' contributions}

EO constructed the model and wrote the manuscript. AFF was responsible for collecting data since the first survey and he suggested the inclusion of the analysis presented on the paper. SPN suggested the inclusion of the statistical indices used in this research and helped with English editing. JKV taught the first author how to build the growth model and did the last review in the English version. All authors read and approved the final manuscript.

\section{Acknowledgements}

We thank CNPq (Brazilian National Council for Scientific and Technological Development) for providing a scholarship to the first author.

\section{Funding}

This research was funded by CNPq (Brazilian National Council for Scientific and Technological Development).

\section{Author details}

${ }^{1}$ Midwest State University-UNICENTRO-PR, PR 153, Km 7, Riozinho, Irati, Paraná 84500-000, Brazil. 'Federal University of Paraná, UFPR. Av. Pref. Lothário Meissner, 900, Jardim Botânico, Curitiba, Paraná 80210-170, Brazil.

${ }^{3}$ Southern Cross University (SCU), PO Box 157, Lismore, NSW, Australia.

\section{Received: 25 February 2016 Accepted: 27 April 2016}

Published online: 06 May 2016

\section{References}

Alder D, Silva J (2000) An empirical cohort model for management of Terra Firme forests in the Brazilian Amazon. For Ecol Manage 130:141-157

Alder D, Oavika F, Sanchez M, Silva JNM, van der Hout P, Wright HL (2002) A comparison of species growth rates from four moist tropical forest regions using increment-size ordination. Int For Rev 4:196-205. doi:10.1505/IFOR.4.3. 196.17398
Behling H, Pillar VD (2007) Late Quaternary vegetation, biodiversity and fire dynamics on the southern Brazilian highland and their implication for conservation and management of modern Araucaria forest and grassland ecosystems. Philos Trans R Soc Lond B Biol Sci 362:243-251. doi:10.1098/rstb.2006.1984

Botkin DB (1993) Forest dynamics: an ecological model. Oxford University Press, Oxford

Carlucci MB, Jarenkow JA, da Silva Duarte L, Pillar VDP (2011) Conservação da Floresta com Araucária no Extremo Sul do Brasil. Nat Conserv 9:111-114. doi:10.4322/natcon.2011.015

Carvalho PER (1994) Espécies florestais brasileiras: recomendações silviculturais, potencialidades e uso da madeira. Embrapa, Colombo

Carvalho PER (2003) Espécies arbóreas brasileiras, 1st edn. Embrapa Florestas, Colombo

Chave J (1999) Study of structural, successional and spatial patterns in tropical rain forests using TROLL, a spatially explicit forest model. Ecol Modell 124: 233-254. doi:10.1016/S0304-3800(99)00171-4

Cook RD, Weisberg S (1999) Applied regression including computing and graphics. John Wiley \& Sons, New York

Easdale TA, Allen RB, Peltzer DA, Hurst JM (2012) Size-dependent growth responses to competition and environment in Nothofagus menziesii. For Ecol Manage 270:223-231. doi:10.1016/j.foreco.2012.01.009

Ebling AA, Watzlawick LF, Rodrigues AL, Longhi SJ, Longhi RV, Abrão SF (2012) Acuracidade da distribuição diamétrica entre métodos de projeção em Floresta Ombrófila Mista. Ciência Rural 42:1020-1026. doi:10.1590/S010384782012000600011

Figueiredo Filho A, Dias AN, Stepka TF, Sawczuk AR (2010) Crescimento, mortalidade, ingresso e distribuição diamétrica em floresta ombrófila mista. Floresta 40:763-776. doi:10.5380/rf.v40i4.20328

Gourlet-Fleury S, Blanc L, Picard N, Sist P, Dick J, Nasi R, Swaine MD, Forni E (2005) Grouping species for predicting mixed tropical forest dynamics: looking for a strategy. Ann For Sci 62:785-796. doi:10.1051/forest:2005084

Groeneveld J, Alves LF, Bernacci LC, Catharino ELM, Knogge C, Metzger JP (2009) The impact of fragmentation and density regulation on forest succession in 
the Atlantic rain forest. Ecol Modell 220:2450-2459. doi:10.1016/j.ecolmodel. 2009.06.015

Huth A, Ditzer T (2000) Simulation of the growth of a lowland Dipterocarp rain forest with FORMIX3. Ecol Modell 134:1-25. doi:10.1016/S03043800(00)00328-8

Kariuki M, Kooyman RM, Brooks L, Smith RGB, Vanclay JK (2006) Modelling growth, recruitments and mortality to describe and simulate dynamics of subtropical rainforests following different levels of disturbance. FBMIS 1:22-47

King DA, Davies SJ, Noor NSM (2006) Growth and mortality are related to adult tree size in a Malaysian mixed dipterocarp forest. For Ecol Manage 223:152-158. doi:10.1016/j.foreco.2005.10.066

Koch Z, Corrêa MC (2002) Araucária: a floresta do Brasil meridional. Olhar Brasileiro, Curitiba

Köhler P, Huth A (1998) The effects of tree species grouping in tropical rain forest modelling Simulations with the individual based model Formind. Ecol Modell 109:301-321

Köhler P, Ditzer T, Ong RC, Huth A (2001) Comparison of measured and simulated growth on permanent plots in Sabah's rain forests. For Ecol Manage 142:1-16

Lana MD, Péllico Netto S, Corte APD, Sanquetta CR, Ebling AA (2015) Prognose da Estrutura Diamétrica em Floresta Ombrófila Mista. Rev Floresta e Ambient 22:71-78

Ledermann T, Eckmüllner O (2004) A method to attain uniform resolution of the competition variable Basal-Area-in-Larger Trees (BAL) during forest growth projections of small plots. Ecol Modell 171:195-206. doi:10.1016/j.ecolmodel. 2003.08.005

Liu J, Ashton PS (1998) FORMOSAIC: an individual-based spatially explicit model for simulating forest dynamics in landscape mosaics. Ecol Modell 106:177-200. doi:10.1016/S0304-3800(97)00191-9

Lujan-Soto JE, Corral-Rivas JJ, Aguirre-Calderón OA, Von Gadow K (2015) Grouping forest tree species on the Sierra Madre Occidental, Mexico. Allg Forst und Jagdzeitung AFJZ 186:63-71

Mello AA de, Eisfeld R de L, Sanquetta CR (2003) Projeção Diamétrica E Volumétrica Da Araucária E Espécies Associadas No Sul Do Paraná, Usando Matriz De Transição. Rev acadêmica ciências agrárias e Ambient 1:55-66

Muetzelfeldt R, Massheder J (2003) The Simile visual modelling environment. Eur J Agron 18:345-358

Newton AC (2007) Forest ecology and conservation: a handbook of techniques. Oxford University Press, Oxford

Phillips PD, Yasman I, Brash TE, van Gardingen PR (2002) Grouping tree species for analysis of forest data in Kalimantan (Indonesian Borneo). For Ecol Manage 157:205-216. doi:10.1016/S0378-1127(00)00666-6

Phillips PD, de Azevedo CP, Degen B, Thompson IS, Silva JNM, van Gardingen PR (2004) An individual-based spatially explicit simulation model for strategic forest management planning in the eastern Amazon. Ecol Modell 173:335-354. doi:10.1016/j.ecolmodel.2003.09.023

Picard N, Mortier F, Rossi V, Gourlet-Fleury S (2010) Clustering species using a model of population dynamics and aggregation theory. Ecol Modell 221: 152-160. doi:10.1016/j.ecolmodel.2009.10.013

Picard N, Köhler P, Mortier F, Gourlet-Fleury S (2012) A comparison of five classifications of species into functional groups in tropical forests of French Guiana. Ecol Complex 11:75-83. doi:10.1016/j.ecocom.2012.03.003

Pretzsch H (2009) Forest dynamics, growth and yield. Springer Berlin Heidelberg, Berlin

Purves D, Pacala S (2008) Predictive models of forest dynamics. Science 320: 1452-1453. doi:10.1126/science.1155359

Pütz S, Groeneveld J, Alves LF, Metzger JP, Huth A (2011) Fragmentation drives tropical forest fragments to early successional states: a modelling study for Brazilian Atlantic forests. Ecol Modell 222:1986-1997. doi:10.1016/j.ecolmodel. 2011.03.038

Sands R (2005) Forestry in a global context. CABI, Wallingford

Sanquetta CR (1999) ARAUSIS: sistema de simulação para manejo sustentável de florestas de Araucária. Floresta 29:115-121. doi:10.5380/rf.v29i12.2321

Stepka TF, Dias AN, Figueiredo Filho A, Machado S, Sawczuk A (2010) Prognose da estrutura diamétrica de uma Floresta Ombrófila Mista com os métodos razão de movimentos e matriz de transição. Pesqui Florest Bras 30:327-335. doi:10.4336/2010.pfb.30.64.327

Tietjen B, Huth A (2006) Modelling dynamics of managed tropical rainforests-An aggregated approach. Ecol Modell 199:421-432. doi:10.1016/j.ecolmodel. 2005.11.045

Vanclay JK (1991a) Aggregating tree species to develop diameter increment equations for tropical rainforests. For Ecol Manage 42:143-168. doi:10.1016/0378-1127(91)90022-N
Vanclay JK (1991b) Mortality functions for North Queensland rain forests. J Trop For Sci 4:15-36

Vanclay JK (1992) Modelling regeneration and recruitment in a tropical rain forest. Can J For Res 22:1235-1248. doi:10.1139/x92-165

Vanclay JK (1994) Modelling forest growth and yield: applications to mixed tropical forests. CABI, Wallingford

Vanclay JK (2003) Growth modelling and yield prediction for sustainable forest management. Malaysian For 66:58-69

Vanclay JK (2012) Modelling continuous cover forests. In: Pukkala T, von Gadow K (eds) Continuous cover forestry, 2nd edn. Springer, New York, pp 229-242

Weiskittel AR, Hann DW, Kershaw JA Jr, Vanclay JK (2011) Forest growth and yield modeling. Wiley-Blackwell, Chichester

Zhao D, Borders B, Wilson M (2004) Individual-tree diameter growth and mortality models for bottomland mixed-species hardwood stands in the lower Mississippi alluvial valley. For Ecol Manage 199:307-322. doi:10.1016/j.foreco.2004.05.043

\section{Submit your manuscript to a SpringerOpen ${ }^{\circ}$ journal and benefit from:}

- Convenient online submission

- Rigorous peer review

- Immediate publication on acceptance

- Open access: articles freely available online

- High visibility within the field

- Retaining the copyright to your article

Submit your next manuscript at $\boldsymbol{s p r i n g e r o p e n . c o m ~}$ 